\title{
Short communication: Association of lying behavior and subclinical ketosis in transition dairy cows
}

\author{
E. I. Kaufman, ${ }^{*}$ S. J. LeBlanc, $†$ B. W. McBride, ${ }^{*}$ T. F. Duffield,† and T. J. DeVries* \\ ${ }^{*}$ Department of Animal Biosciences, and \\ †Department of Population Medicine, University of Guelph, 50 Stone Road East, Guelph, Ontario, N1G 2W1, Canada
}

\begin{abstract}
The objective of this study was to characterize the association of lying behavior and subclinical ketosis (SCK) in transition dairy cows. A total of 339 dairy cows (107 primiparous and 232 multiparous) on 4 commercial dairy farms were monitored for lying behavior and SCK from $14 \mathrm{~d}$ before calving until $28 \mathrm{~d}$ after calving. Lying time, frequency of lying bouts, and average lying bout length were measured using automated data loggers $24 \mathrm{~h} / \mathrm{d}$. Cows were tested for SCK $1 \times /$ wk by taking a blood sample and analyzing for $\beta$-hydroxybutyrate; cows with $\beta$-hydroxybutyrate $\geq 1.2 \mathrm{mmol} / \mathrm{L}$ postpartum were considered to have SCK. Cases of retained placenta, metritis, milk fever, or mastitis during the study period were recorded and cows were categorized into 1 of 4 groups: healthy (HLT) cows had no SCK or any other health problem ( $\mathrm{n}=$ 139); cows treated for at least 1 health issue other than SCK $(\mathrm{n}=50)$; SCK (HYK) cows with no other health problems during transition $(\mathrm{n}=97)$; or subclinically ketotic plus $(\mathrm{HYK}+)$ cows that had SCK and 1 or more other health problems $(\mathrm{n}=53)$. Daily lying time was summarized by week and comparisons were made between HLT, HYK, and HYK+, respectively. We found no difference among health categories in lying time, bout frequency, or bout length from wk -2 to wk +4 relative to calving for first-lactation cows. Differences in lying time for multiparous cows were seen in wk +1 , when HYK + cows spent $92 \pm 24.0 \mathrm{~min} / \mathrm{d}$ more time lying down than HLT cows, and during wk +3 and +4 when HYK cows spent $44 \pm 16.7$ and $41 \pm 18.9 \mathrm{~min} / \mathrm{d}$, respectively, more time lying down than HLT cows. Increased odds of HYK+ were found to be associated with higher parity, longer dry period, and greater stall stocking density in wk -1 and longer lying time during wk +1 . When comparing HYK to HLT cows, the same variables were associated with odds of SCK; however,
\end{abstract}

Received March 17, 2016.

Accepted June 2, 2016.

${ }^{1}$ Corresponding author: tdevries@uoguelph.ca lying time was not retained in the final model. These results suggest that monitoring lying time may contribute to identifying multiparous cows experiencing SCK with another health problem after calving, but may not be useful in the early detection of SCK.

Key words: transition dairy cow, health, lying behavior, subclinical hyperketonemia

\section{Short Communication}

Technological improvements have enhanced on-farm detection of subclinical ketosis (SCK), also referred to as hyperketonemia. Cows in negative energy balance (NEB) begin to mobilize fat stores in an attempt to meet their high energy needs during early lactation, resulting in a release of ketone bodies, including BHB, into the blood (Bauman and Currie, 1980; Goldhawk et al., 2009; LeBlanc, 2010). Electronic cow-side tests for the quantification of blood BHB concentration have been validated in dairy cows (Iwersen et al., 2009; Voyvoda and Erdogan, 2010). Despite such tests being available, it is still challenging to for dairy producers to identify SCK at an early stage. Evidence is growing that measurements of activity and feeding behavior may be used to preemptively identify cows at risk for subclinical illness (Weary et al., 2009). In addition to feeding behavior (Goldhawk et al., 2009), rumination time (Soriani et al., 2012; Liboreiro et al., 2015; Kaufman et al., 2016), and walking activity (Edwards and Tozer, 2004), potential exists for SCK to be identified through changes in lying behavior. Lying behavior may be a promising indicator of metabolic conditions, particularly during the peripartum period. Itle et al. (2015) recently found that cows with SCK after calving spent less time lying in the week before calving. Those authors suggested that cows with SCK were potentially socially subordinate cows who spent more time standing, waiting to access the feed bunk. On the other hand, behavior may also change in response to disease. Cows with SCK are in a state of excessive NEB, as ketone bodies in the blood rise with low glucose availability (Ingvartsen, 2006); thus, it could be hypothesized that cows with SCK may spend more time lying down to 
decrease energy expenditure. Increased lying time in sick cows agrees with the concept that sick animals become less active in attempt to conserve energy needed to facilitate recovery (Hart, 1988; Dantzer and Kelley, 2007).

Therefore, the objective of our study was to characterize changes in lying behaviors across the transition period and determine if lying time, frequency of lying bouts, and lying bout duration may be associated with SCK. We hypothesized that dairy cows with increased lying activity, both pre- and postcalving, would be at higher risk of experiencing SCK in early lactation.

This research was part of a larger study aimed at evaluating the usefulness of rumination monitoring for the early detection of SCK. As such, detailed descriptions of the methodology are presented in Kaufman et al. (2016). In summary, a total of 339 dairy cows (107 primiparous and 232 multiparous) on 4 commercial dairy farms were monitored for lying behavior and SCK from $14 \mathrm{~d}$ before calving until $28 \mathrm{~d}$ after calving. All cows were housed in freestall facilities and milked in a parlor $3 \times / d$. Three farms housed close-up dry cows on a straw-bedded pack and the fourth farm housed closeup cows in a digestate-bedded freestall pen. For fresh and lactating cows, 2 farms bedded with sand, 1 with wood shavings, and the last with digestate bedding. Stall stocking density was calculated on a weekly basis. Freestall stocking density was calculated by dividing the number of cows by the number of stalls in each pen $\times 100 \%$. Bedded pack stocking density was calculated by first dividing the pack dimensions $\left(\mathrm{m}^{2}\right)$ by the recommended space allowance for transition cows (11 $\mathrm{m}^{2}$; Nordlund, 2009), and dividing the number of cows in each bedded pack by this value $\times 100 \%$. Using this calculation, $100 \%$ stocking density in bedded packs was equivalent to providing $11 \mathrm{~m}^{2}$ of space per cow.

Animal use and study design were approved by the University of Guelph's Animal Care Committee (AUP\#2518) and Research Ethics Board (REB\#14JA015), respectively. A blood sample was taken from the coccygeal vein of each cow for measurement of BHB $1 \times /$ wk; BHB was measured using an electronic hand-held device (Precision Xtra meter, Abbott Diabetes Care, Saint Laurent, QC, Canada), as validated by Iwersen et al. (2009). Cows with BHB $\geq 1.2 \mathrm{mmol} / \mathrm{L}$ at one or more weekly sample postpartum were considered to have SCK (Geishauser et al., 1998; McArt et al., 2012). Of the 339 cows tested, 150 had at least $1 \mathrm{BHB}$ value $\geq 1.2 \mathrm{mmol} / \mathrm{L}$. Of these cows with SCK, 78 had only 1 out of 4 BHB values $\geq 1.2$ $\mathrm{mmol} / \mathrm{L}$, whereas 72 had more than $1 \mathrm{BHB}$ value $\geq 1.2$ $\mathrm{mmol} / \mathrm{L}$. Producer-reported cases of retained placenta, metritis, milk fever, or mastitis during the study period were also recorded. To minimize the potential variation in definition of producer-reported disease, producers were provided standardized definitions for these conditions, as described in Kaufman et al. (2016). Cows were categorized into 1 of 4 groups: healthy (HLT) cows had no SCK or any other recorded clinical disease (n $=139)$; healthy plus $(\mathbf{H L T}+)$ cows were not diagnosed with SCK but were treated for at least 1 other health problem $(\mathrm{n}=50)$; SCK $(\mathbf{H Y K})$ cows with no other health problems during transition $(\mathrm{n}=97)$; or subclinically ketotic plus $(\mathbf{H Y K}+)$ cows that had SCK and 1 or more other clinical diseases $(\mathrm{n}=53)$.

All enrolled cows were affixed, weekly, with a data logger (Onset Hobo Pendant G data loggers; Onset Computer Corporation, Bourne, MA) to record standing and lying behavior for $7 \mathrm{~d}$, as validated by Ledgerwood et al. (2010). Individual data loggers were placed on the medial side of a hind leg, and secured with bandaging wrap (Vetrap Bandaging Tape, 3M, London, ON, Canada). To ensure accurate and consistent collection of data, each data logger was positioned identically on each cow as described by Ledgerwood et al. (2010). During each weekly farm visit, another data logger was attached to the cow's opposite hind leg and the data logger that had been recording data for the past week was removed. Data were downloaded weekly; recordings were used to calculate daily measurements of lying time $(\mathrm{min} / \mathrm{d})$, frequency of lying bouts (no. of bouts/d), and average lying bout length ( $\mathrm{min} /$ bout; UBC AWP, 2013).

Cows that had aborted $(\mathrm{n}=2)$, were culled $(\mathrm{n}=$ $2)$, or diagnosed ketotic $(\mathrm{n}=3)$ before calving were not included in the statistical analysis. Cows that were sold $(n=22)$ or died $(n=1)$ during the postcalving period, with behavioral and health measurements recorded until the day they left the herd, were included in the analysis. Descriptive statistics were calculated on 339 cows (107 primiparous and 232 multiparous) categorized as HLT $(\mathrm{n}=139)$, HLT $+(\mathrm{n}=50)$, HYK $(\mathrm{n}=97)$, and HYK $+(\mathrm{n}=53)$. The linear and logistic models compared the measures of lying behavior between HYK cows and HLT cows as well as HYK+ cows and HLT cows, respectively; HLT + cows were not included in this analysis. Due to limitations in sample size, the current study did not have enough power (see description of power analysis in Kaufman et al., 2016) to compare lying behavior of cows with 1 positive SCK test to those that had $>1$ positive SCK test.

Statistical analyses were performed with SAS (version 9.4; SAS Institute Inc., Cary, NC) using cow $(\mathrm{n}=289)$ within farm as the experimental unit. Daily lying times (min/d), frequency of lying bouts per day (bouts/d), and lying bout lengths ( $\mathrm{min} /$ bout) were each summarized by cow and week (14 to $8 \mathrm{~d}$ before calving, 7 to $1 \mathrm{~d}$ before calving, 1 to 7 DIM, 8 to 14 DIM, 15 to 21 
DIM, and 22 to 28 DIM), such that these data aligned with the once weekly testing of SCK. These data were analyzed in a general linear mixed model (MIXED procedure in SAS), treating week as a repeated measure. Separate models were used to analyze lying time, bout frequency, and bout length. Initially, farm was included as a fixed effect to determine if any farm-level factors (e.g., bedding type) had an effect on lying behaviors; no significant effect was found. Thus, farm was included in each model as a random effect as well as cow within farm (subject of repeated statement). The fixed effects in each model were health status, parity, and week, the interactions of health status by parity and health status by week, as well as the 3-way interaction of health status, parity, and week. The covariance structure was heterogeneous compound symmetry, selected by best fit according to Schwarz's Bayesian information criterion. A 3-way interaction was found between health status, parity, and week $(P<0.001)$ when analyzing lying time and frequency of lying bouts; thus, first-lactation and multiparous (Mp) cows were analyzed separately. These separate models included the fixed effects of health status, week, and the interaction between health status by week, with farm and cow within farm (subject of repeated statement) included as random effects. Differences in lying behavior between health categories and weeks were compared using the least squares means procedure with the PDIFF function. Significance was declared at $P \leq 0.05$, and tendencies were reported if $0.05<P \leq 0.10$.

In the analysis of the effect of health status on lying behaviors, as described above, differences were only found between health categories for Mp cows. Thus, multivariable logistic regression analysis was only performed on data from $\mathrm{Mp}$ cows and not on primiparous $(\mathbf{P p})$ cows. The analysis was performed using the GLIMMIX procedure (distribution $=$ binomial and link $=$ logit) in SAS (version 9.4; SAS Institute Inc.) to model the effects of lying behavior and other cow-level factors (as measured and described in Kaufman et al., 2016) on the presence or absence of SCK. This was done using 2 different models: one model compared HYK to HLT cows whereas the other compared HYK+ to HLT cows. Farm and cow within farm were included as random effects in these models. Parity and precalving BCS were both treated as categorical variables. Multiparous cows were characterized as second lactation $(\mathrm{n}=99)$ or third lactation and greater $(\mathrm{n}=103)$. Body condition precalving was categorized into 3 groups: underweight, BCS $<3$; normal, BCS $=3$ to 3.5 ; overweight, BCS $>3.5$. Parity, precalving BCS category, change in BCS over the transition period (BCS at enrollment - BCS at time of removal from study), length of dry period, milk yield from the previous lactation, as well as lying time, frequency of lying bouts, lying bout length, and stall stocking density during the weeks before the mean day of diagnosis (wk $-2,-1$, and +1 ), were all assessed for an association with presence or absence of HYK and HYK + using univariable logistic regression models. Variables with $P \leq 0.25$ were then used to construct a multivariable logistic regression model. The CORR procedure in SAS was used to check for correlations between the explanatory variables included in the multivariable model. If 2 variables were highly correlated ( $\mathrm{r}$ $>|0.8|)$, the variable with the lowest $P$-value and most biological relevance was retained for the multivariable model. Manual backward elimination of nonsignificant and nontrending $(P>0.10)$ variables was used to create the final models and, from the resultant models, plausible 2-way interactions were examined and retained if $P \leq 0.10$. Only those variables retained in the final multivariable models are presented.

Figure 1a illustrates how the frequency of lying bouts evolved across the transition period for both the Pp and $\mathrm{Mp}$ cows. Other researchers observing cows in freestall facilities have reported similar frequencies of lying bouts for transition cows: $\sim 10.5$ (Calderon and Cook, 2011) and $11.1 \pm 0.4$ bouts/d (Steensels et al., 2012). The Pp cow model for frequency of lying bouts showed no effects of health status $(P=0.3)$, week $(P=$ $0.7)$, or interaction between these variables $(P=0.9)$. Health status did not show an effect on frequency of lying bouts for Mp cows $(P=0.3)$, but week did have an effect $(P<0.001)$. The Mp cows had fewer lying bouts in wk $-2(9 \pm 0.4$ bouts/d) compared with wk -1 (11 \pm 0.4 bouts/d), but frequency of lying bouts decreased $(P<0.01)$ each week moving from wk +1 to $+3(11 \pm 0.4,9 \pm 0.4$, and $9 \pm 0.4$ bouts $/ \mathrm{d}$ for $\mathrm{wk}$ $+1,+2$, and +3 , respectively). The difference between parities $(P=0.04)$ in the frequency of lying bouts over the entire transition period (Pp: $10.4 \pm 0.53$ vs. Mp: 9.6 \pm 0.46 bouts $/ \mathrm{d}$ ) is similar to that reported by a study on cows that had access to pasture (Pp: $9.7 \pm 0.54$ vs. Mp: $8.4 \pm 0.26$ bouts/d; Sepúlveda-Varas et al., 2014). Proudfoot et al. (2009) demonstrated that cows with dystocia had more frequent transitions between standing and lying; thus, it could be hypothesized that the observed difference in the present study between $\mathrm{Pp}$ and Mp may be due to differences in calving ease. As calving ease was not recorded in the present study, we recommend this be researched further.

Figure 1b illustrates how lying bout length evolved across the transition period for both the $\mathrm{Pp}$ and $\mathrm{Mp}$ cows. Lying bout length changed by week $(P<0.001)$, but was not affected by health status $(P=0.28)$. All cows showed a decrease $(P<0.001)$ in lying bout length each week from wk -2 to $+1(88 \pm 4.1 \mathrm{~min}, 74 \pm 3.6$ $\min , 63 \pm 3.4 \mathrm{~min}$ for $\mathrm{wk}-2,-1$, and +1 , respectively), 
a)

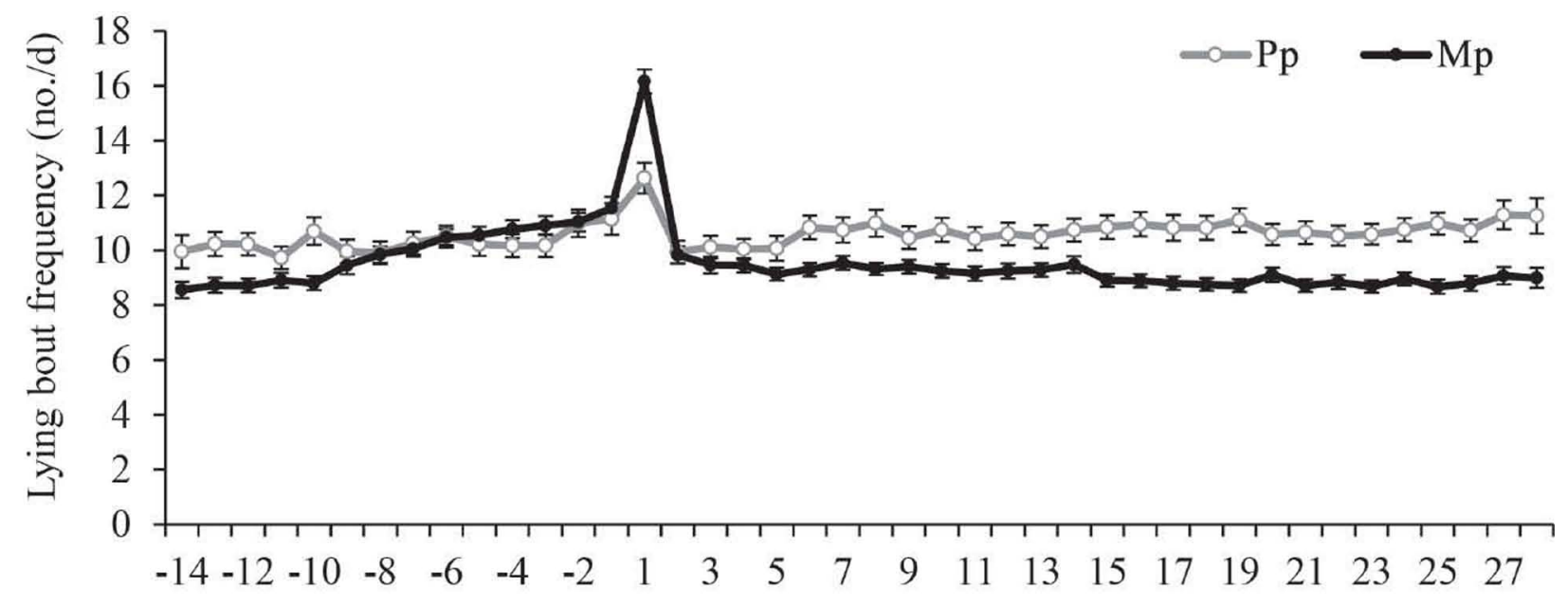

b)

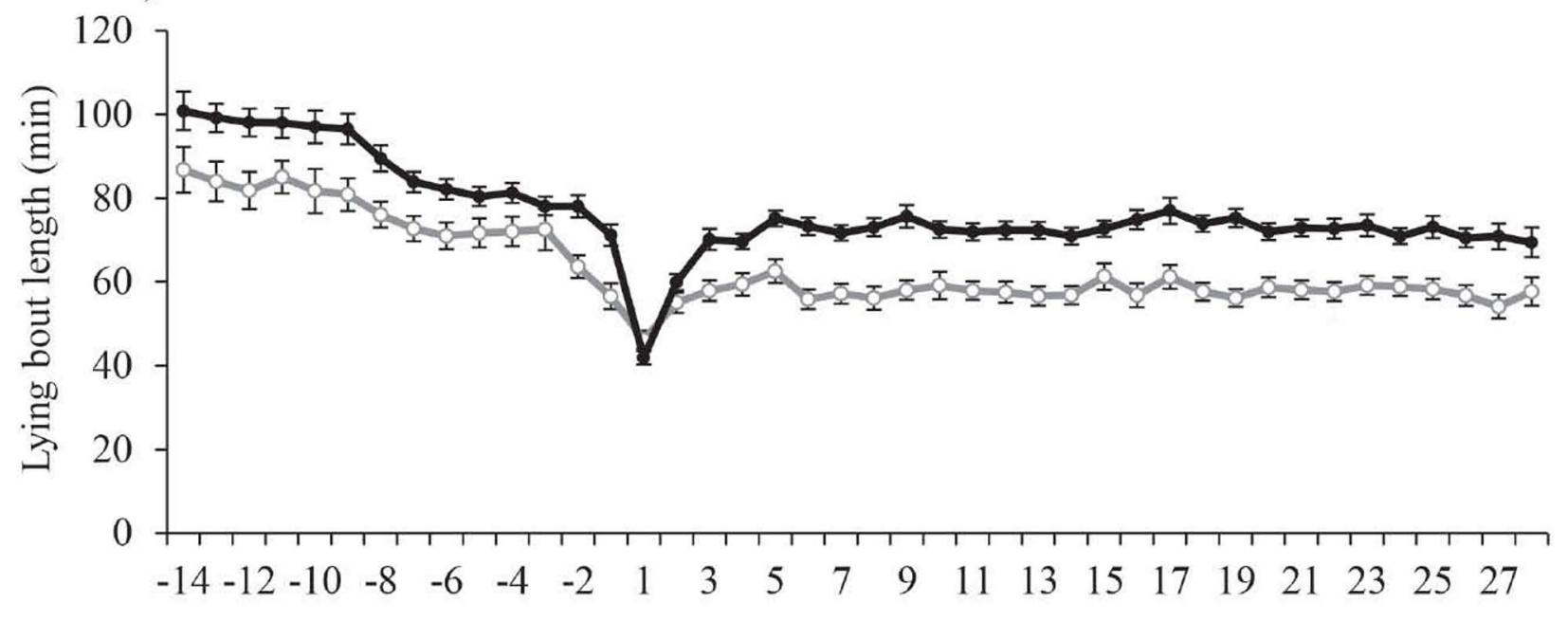

c)

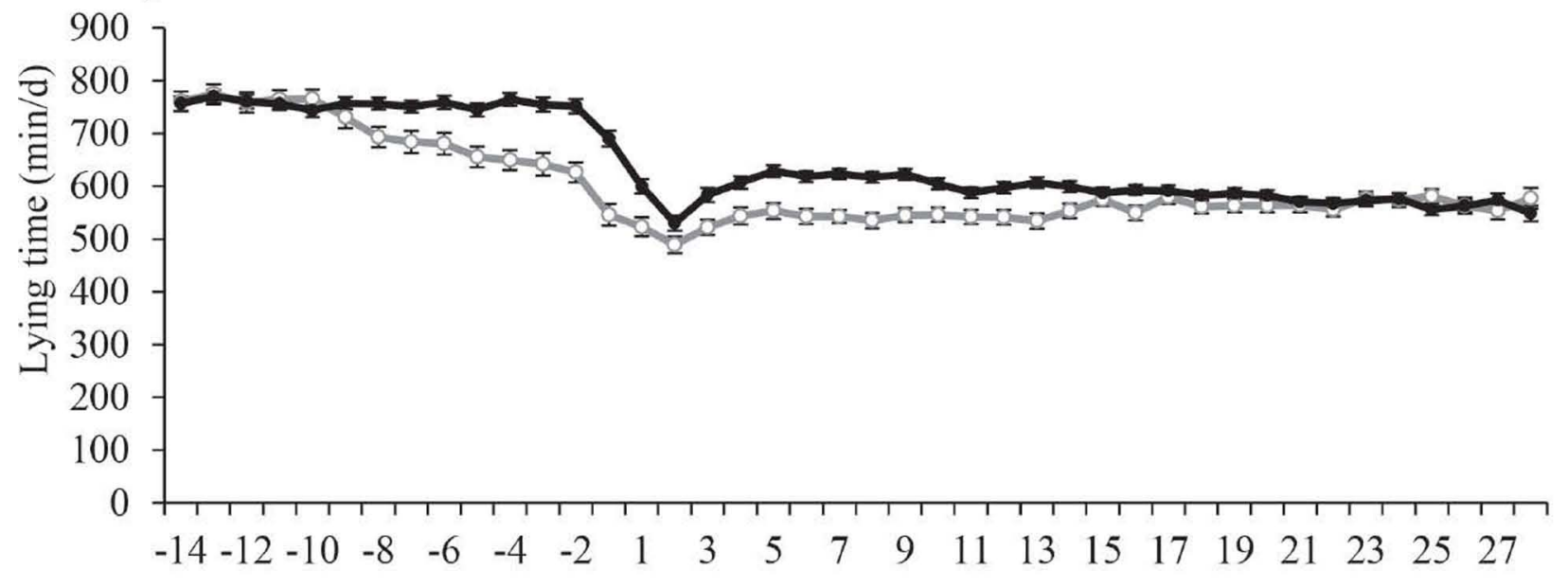

Day relative to calving

Figure 1. Daily (a) lying time (mean $\pm \mathrm{SE} ; \mathrm{min} / \mathrm{d}$ ), (b) lying bout frequency (mean $\pm \mathrm{SE}$; no. of bouts/d), and (c) lying bout length (mean $\pm \mathrm{SE} ; \mathrm{min})$ over the transition period $(-14$ to $28 \mathrm{~d})$ for multiparous $(\mathrm{Mp} ; \mathrm{n}=232)$ and primiparous $(\mathrm{Pp} ; \mathrm{n}=107)$ cows. 
but moving into wk +2 bout length increased $(67 \pm 3.5$ min; $P<0.001)$. Over the transition period, Pp cows had shorter lying bout durations compared with $\mathrm{Mp}$ cows $(P<0.001)$. Sepúlveda-Varas et al. (2014) also found $\mathrm{Pp}$ cows to have shorter lying bouts; however, bout duration for $\mathrm{Pp}$ and $\mathrm{Mp}$ cows did not change over the transition period in that study.

Figure 1c illustrates how daily lying time evolved across the transition period for both the $\mathrm{Pp}$ and $\mathrm{Mp}$ cows. Primiparous cows had lower lying times $(P<$ 0.001) compared with Mp cows. Steensels et al. (2012) reported, in a study of $\mathrm{Mp}$ cows milked $3 \times / \mathrm{d}$, that these cows lay down between 491 and $579 \mathrm{~min} / \mathrm{d}$ in the first $28 \mathrm{~d}$ after calving. The difference between parities observed in the present study agrees with that reported by Sepúlveda-Varas et al. (2014), who found that Pp cows spent less time lying down than Mp cows on pasture during the transition period. Steensels et al. (2012) hypothesized that higher lying times in later parities may be due to increased BW with age.

From 2 wk before calving until 4 wk after calving, HLT, HYK, and HYK + cows in their first lactation showed no difference $(P=0.4)$ in lying time; however, we noted an effect of week $(P<0.001)$. The lying time of Pp cows decreased each week from wk -2 to +1 ( 727 $\pm 28.8,630 \pm 29.9$, and $536 \pm 25.0 \mathrm{~min} / \mathrm{d}$ for $\mathrm{wk}-2$, -1 , and +1 , respectively). Lying time also decreased for all Mp cows moving from wk -1 to +1 (737 \pm 20.4 and $613 \pm 19.5 \mathrm{~min} / \mathrm{d}$ for $\mathrm{wk}-1$ and +1 , respectively; $P<0.001)$. Calderon and Cook (2011) saw lying time decrease for both $\mathrm{Pp}$ and $\mathrm{Mp}$ cows from $\mathrm{d}-16$ until calving, and postcalving lying time restabilize at roughly 590 to $650 \mathrm{~min} / \mathrm{d}$. Another study monitoring changes in standing and lying behavior from -10 to $10 \mathrm{~d}$ relative to calving observed lying time to be 702 $\mathrm{min} / \mathrm{d}$ precalving and $636 \mathrm{~min} / \mathrm{d}$ postcalving (Huzzey et al., 2005), similar to the pattern in the current study. It can be hypothesized that cows spend more time standing postcalving because they are dedicating more of their time to milking, as well as feeding, to support milk production (Huzzey et al., 2005; Gomez and Cook, 2010).

Figure 2 illustrates how the daily lying time evolved across the transition period for HLT, HYK, and HYK+ multiparous cows. An interaction of health status and week was detected $(P<0.001)$ when comparing the lying time of Mp cows. Differences in lying time were seen for Mp cows in wk +3 and +4 , when HYK cows spent more time $(P \leq 0.03)$ lying down per day (19 \pm 20.7 and $41 \pm 18.9 \mathrm{~min} / \mathrm{d}$, respectively) than HLT cows. In addition, HYK cows tended $(P=0.08)$ to lie down $35 \pm 19.7$ and $31 \pm 17.6 \mathrm{~min} / \mathrm{d}$ longer during wk +1 and +2 , respectively. As the major difference in lying time was seen during wk +3 and $+4(P \leq 0.05)$, and the average day of SCK diagnosis was 7 DIM, we hypothesized that because these cows were ill they spent more time lying down (Hart, 1988; Dantzer and Kelley, 2007). Interestingly, another study found that cows with clinical ketosis postpartum stood longer per day during the week before calving (Itle et al., 2015), which was not observed in the present study. Itle et al. (2015) suggested that the cows that later developed ketosis may have been more socially subordinate and, therefore, spent more time standing waiting to feed rather than competing for a spot at the feed bunk. Due to these longer wait times, subordinate cows may have consumed less feed in the week before calving, putting them at a greater risk for SCK.

Differences in lying time were seen also for Mp cows in wk +1 when HYK + cows spent more $(P<0.001)$ time $(92 \pm 24.0 \mathrm{~min} / \mathrm{d})$ lying down than HLT cows, and during wk +2 when HYK + cows tended $(P=0.08)$ to spend more time $(38 \pm 21.4 \mathrm{~min} / \mathrm{d})$ lying down than HLT cows. Sepúlveda-Varas et al. (2014) looked at the postcalving differences in lying time between cows with no health problems or lameness and compared them to cows with one and cows with greater than one clinical postpartum disease (excluding lameness). Cows in their study with multiple illnesses showed greater changes in lying time than those with only one illness, which was also observed in the present study. However, contrary to our results, in the study by Sepúlveda-Varas et al. (2014) Pp cows with more than one illness had greater lying times during the first few days postcalving. No difference in lying time was seen between these groups in Mp cows; Sepúlveda-Varas et al. (2014) suggested this was because Mp cows may have been able to cope better with illness compared with Pp cows.

Similar to Kaufman et al. (2016), in the multivariable models comparing HLT and HYK multiparous cows (Table 1) and HLT and HYK+ multiparous cows (Table 2), it was found that higher parity (third or higher compared with second-lactation cows), longer dry period, greater loss in BCS over the transition period, and greater stall stocking density in wk -1 were all associated with increased odds of SCK. Lying time was not retained the model comparing HLT and HYK cows (Table 1). As only a tendency for HYK cows to lie down longer was noted during the week after calving, this difference in lying time was not large enough to be associated with increased odds of SCK. We did find, however, that longer lying time per day during wk +1 was associated with having increased odds of SCK with at least one other clinical disease (Table 2).

Several researchers have observed various associations between lying behavior and postpartum illnesses. Proudfoot et al. (2009) found cows with dystocia to have a greater number of lying bouts compared with 


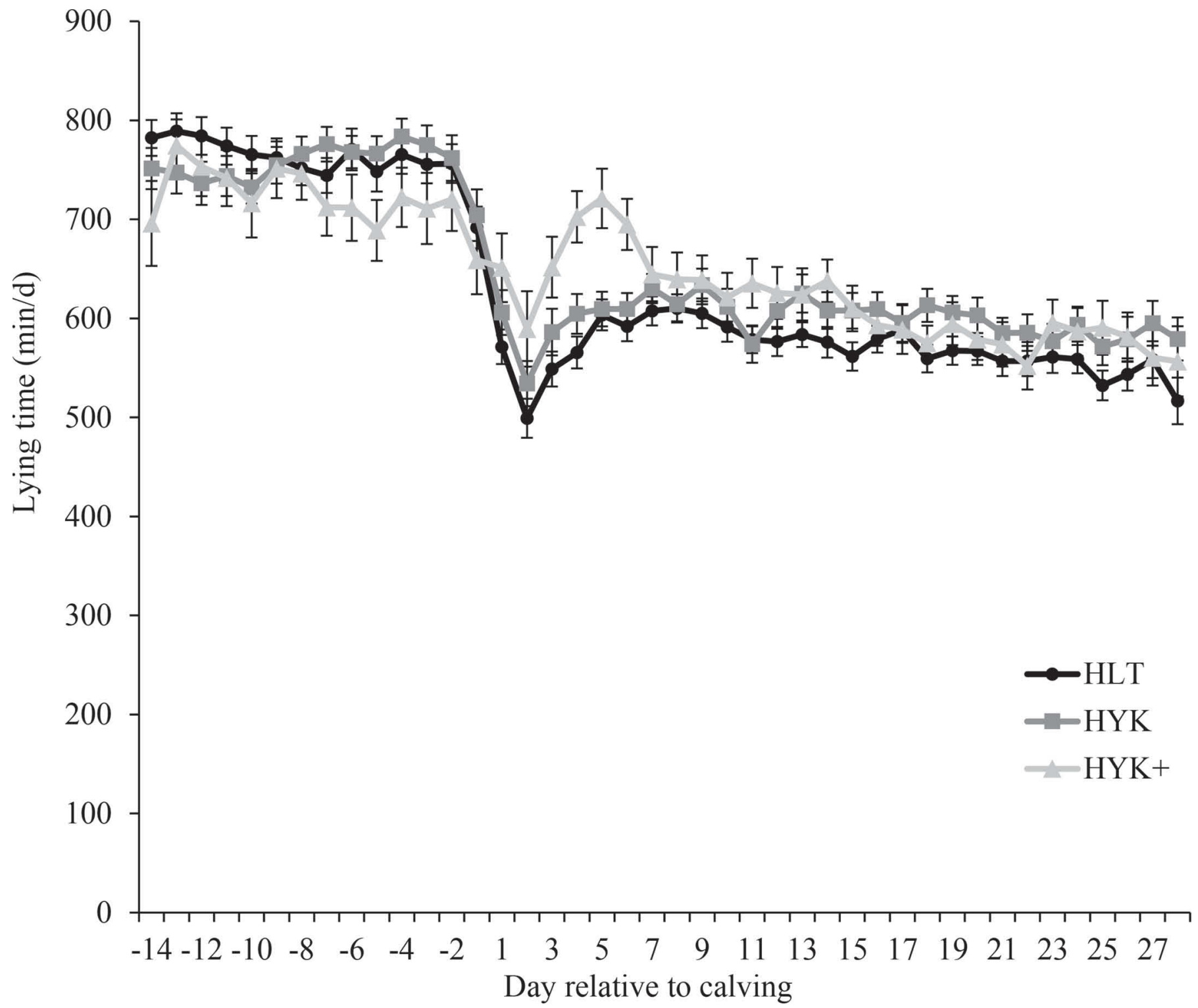

Figure 2. Average daily lying time (mean $\pm \mathrm{SE}$; $\mathrm{min} / \mathrm{d}$ ) over the transition period ( -14 to $28 \mathrm{~d}$ ) for healthy multiparous (Mp) cows with no other illnesses (HLT; $\mathrm{n}=87$ ), subclinically ketotic Mp cows with no other health problems (HYK; $\mathrm{n}=76)$, and subclinically ketotic Mp cows with other health problems (HYK+; $\mathrm{n}=39)$.

cows without calving difficulty in the $48 \mathrm{~h}$ before calving, which persisted until $48 \mathrm{~h}$ postcalving. A study that looked at standing behavior of hypocalcemic cows found these cows lay down less during the $24 \mathrm{~h}$ before calving, but they lay down longer in the week after calving (Jawor et al., 2012). Itle et al. (2015) found clinically ketotic cows lay down less throughout the week before calving than healthy cows, but saw no difference in lying time postcalving. The mean day of diagnosis for SCK in the current study was 7 DIM. Cows with SCK are in a state of NEB and may lie down for longer periods to conserve energy (Hart, 1988) needed for milk production. It may also be that cows that spend more time lying down are spending less time at the feed bunk and, therefore, are consuming less feed. Goldhawk et al. (2009) found cows with SCK spent less time at the feeder, visited the feeder fewer times, and consumed less DM during the week before calving. From our data, we cannot determine if SCK and other illnesses are directly causing the increase in lying behavior or vice versa; however, future research that aims to understand the motivation behind lying behavior in sick cows may be beneficial in identifying subclinical illness preemptively. 
Table 1. Final logistic regression model for factors associated with the incidence of subclinical ketosis with no other health issues (HYK; $\mathrm{n}=76$ ) relative to healthy animals (HLT; $\mathrm{n}=87$ ), in multiparous cows

\begin{tabular}{|c|c|c|c|c|}
\hline Variable & Coefficient & $\mathrm{SE}$ & $\begin{array}{l}\text { Odds ratio } \\
(95 \% \mathrm{CI})^{1}\end{array}$ & $P$-value \\
\hline Intercept & -5.02 & 1.456 & - & 0.041 \\
\hline Parity & & & & 0.004 \\
\hline 2 & - & - & Referent & - \\
\hline $3+$ & 1.15 & 0.393 & $3.17(1.46,6.90)$ & - \\
\hline Length of dry period (d) & 0.03 & 0.017 & $1.80(0.95,3.40)$ & 0.069 \\
\hline Change in $\mathrm{BCS}^{2}$ & 1.47 & 0.550 & $1.72(1.15,2.58)$ & 0.0086 \\
\hline $\begin{array}{l}\text { Stall stocking density }{ }^{3}(\%) \\
\text { wk }-1\end{array}$ & 0.02 & 0.009 & $1.75(1.14,2.67)$ & 0.011 \\
\hline
\end{tabular}

${ }^{1}$ Adjusted odds- ratio and 95\% CI for $1 \mathrm{SD}$ increase in each variable in the model. The mean \pm SD for each variable are as follows: $59 \pm 19 \mathrm{~d}$, dry period length; $0.5 \pm 0.37$, change in BCS; $80 \pm 24.8 \%$, stocking density (wk-1).

${ }^{2}$ Change in BCS $=$ BCS at enrollment - BCS at time of removal of study.

${ }^{3}$ Stall stocking density for freestall pens was calculated as (no. of cows in pen)/(no. of stalls). Bedded packs were calculated (no. of cows in bedded pack)/[(dimensions, $\left.\mathrm{m}^{2}\right) /\left(\right.$ recommended space allowance, $\left.\left.11 \mathrm{~m}^{2}\right)\right]$ (Nordlund, 2009).

The current study found a 131-min increase (1 SD above the mean of $601 \mathrm{~min} / \mathrm{d}$ ) in lying time per day during the week after calving was associated with 1.8-times higher odds of being HYK+. Kaufman et al. (2016) found that the odds of developing SCK and another health problem were 2.0 times greater for every $87 \mathrm{~min} / \mathrm{d}$ decrease (1 SD below the mean of $407 \mathrm{~min} / \mathrm{d}$ ) in rumination time during the week after calving. These results suggest that for monitoring behavior during the week after calving, rumination time may be a better predictor, as compared with lying time, for identifying cows experiencing SCK in combination with at least 1 other health problem.

In conclusion, Mp cows had a greater lying time, fewer lying bouts, and longer lying bout durations compared with Pp cows during the transition period. Primiparous cows showed no difference in lying time or frequency or duration of lying bouts between health statuses; how- ever, multiparous HYK and HYK+ cows were found to lie down longer than multiparous HLT cows during the postcalving period. Further, increased odds of SCK occurring with another postpartum health issue $(\mathrm{HYK}+)$ was associated with longer lying time during the week after calving. Overall, these results suggest that monitoring lying behavior across the transition period may not be useful for the early identification of SCK, but may contribute to the identification of $\mathrm{Mp}$ cows that have SCK in combination with another health issue.

\section{ACKNOWLEDGMENTS}

We thank all participating farms for allowing us to collect data on their herds. We are grateful to Robin Crossley, Lisa Gordon, Morgan Overvest, Caylie Corvinelli, and Hannah Gillespie of the University of Guelph, Kemptville Campus (Kemptville, ON, Canada) for all

Table 2. Final logistic regression model for factors associated with the incidence of subclinical ketosis with other health problems (HYK $+\mathrm{n}=39$ ) relative to healthy animals (HLT; $\mathrm{n}=87$ ), in multiparous cows

\begin{tabular}{|c|c|c|c|c|}
\hline Variable & Coefficient & $\mathrm{SE}$ & $\begin{array}{l}\text { Odds ratio } \\
(95 \% \mathrm{CI})^{1}\end{array}$ & $P$-value \\
\hline Intercept & -9.06049 & 2.6301 & - & 0.035 \\
\hline Parity & & & & 0.0037 \\
\hline 2 & - & - & Referent & - \\
\hline $3+$ & 1.72 & 0.580 & $5.6(1.78$ to 1.80$)$ & - \\
\hline Length of dry period (d) & 0.049 & 0.0291 & $2.5(0.84$ to 7.59$)$ & 0.097 \\
\hline $\begin{array}{l}\text { Stall stocking density }{ }^{2}(\%) \\
\text { wk }-1\end{array}$ & 0.026 & 0.0130 & $1.9(1.00$ to 3.60$)$ & 0.049 \\
\hline $\begin{array}{l}\text { Lying time }(\min / \mathrm{d}) \\
\mathrm{wk}+1\end{array}$ & 0.0046 & 0.00235 & 1.8 (1.00 to 3.39$)$ & 0.051 \\
\hline
\end{tabular}

${ }^{1}$ Adjusted odds ratio and 95\% CI for $1 \mathrm{SD}$ increase in each variable in the model. The mean \pm SD for each variable are as follows: $59 \pm 19.0 \mathrm{~d}$, length of dry period; $80 \pm 24.8 \%$, stocking density (wk -1$) ; 601 \pm 131.3$ $\min / \mathrm{d}$, lying time $(\mathrm{wk}+1)$.

${ }^{2}$ Stall stocking density for freestall pens was calculated as (no. of cows in pen)/(no. of stalls). Bedded packs were calculated (no. of cows in bedded pack)/[(dimensions, $\left.\mathrm{m}^{2}\right) /\left(\right.$ recommended space allowance, $\left.\left.11 \mathrm{~m}^{2}\right)\right]$ (Nordlund, 2009). 
their technical help during data collection. Financial support for this research was received from the Natural Sciences and Engineering Research Council (Ottawa, ON, Canada), as well as from the Ontario Ministry of Agriculture and Food-University of Guelph Research Partnership (Guelph, ON, Canada).

\section{REFERENCES}

Bauman, D. E., and W. B. Currie. 1980. Partitioning of nutrients during pregnancy and lactation: A review of mechanisms involving homeostasis and homeorhesis. J. Dairy Sci. 63:1514-1529. http:// dx.doi.org/10.3168/jds.S0022-0302(80)83111-0.

Calderon, D. F., and N. B. Cook. 2011. The effect of lameness on the resting behavior and metabolic status of dairy cattle during the transition period in a freestall-housed dairy herd. J. Dairy Sci. 94:2883-2894. http://dx.doi.org/10.3168/jds.2010-3855.

Dantzer, R., and K. W. Kelley. 2007. Twenty years of research on cytokine-induced sickness behavior. Brain Behav. Immun. 21:153-160. http://dx.doi.org/10.1016/j.bbi.2006.09.006.

Edwards, J. L., and P. R. Tozer. 2004. Using activity and milk yield as predictors of fresh cow disorders. J. Dairy Sci. 87:524-531. http:// dx.doi.org/10.3168/jds.S0022-0302(04)73192-6.

Geishauser, T., K. Leslie, D. Kelton, and T. Duffield. 1998. Evaluation of five cowside tests for use with milk to detect subclinical ketosis in dairy cows. J. Dairy Sci. 81:438-443. http://dx.doi org/10.3168/jds.S0022-0302(98)75595-X.

Goldhawk, C., N. Chapinal, D. M. Veira, D. M. Weary, and M. A. G. von Keyserlingk. 2009. Prepartum feeding behavior is an early indicator of subclinical ketosis. J. Dairy Sci. 92:4971-4977. http:// dx.doi.org/10.3168/jds.2009-2242.

Gomez, A., and N. B. Cook. 2010. Time budgets of lactating dairy cattle in commercial freestall herds. J. Dairy Sci. 93:5772-5781. http://dx.doi.org/10.3168/jds.2010-3436.

Hart, B. L. 1988. Biological basis of the behavior of sick animals. Neurosci. Biobehav. Rev. 12:123-137. http://dx.doi.org/10.1016/ S0149-7634(88)80004-6.

Huzzey, J. M., M. A. G. von Keyserlingk, and D. M. Weary. 2005 Changes in feeding, drinking, and standing behavior of dairy cows during the transition period. J. Dairy Sci. 88:2454-2461. http:// dx.doi.org/10.3168/jds.S0022-0302(05)72923-4.

Ingvartsen, K. L. 2006. Feeding and management related diseases in the transition cow. Anim. Feed Sci. Technol. 126:175-213. http:// dx.doi.org/10.1016/j.anifeedsci.2005.08.003.

Itle, A. J., J. M. Huzzey, D. M. Weary, and M. A. G. von Keyserlingk. 2015. Clinical ketosis and standing behavior in transition cows. J. Dairy Sci. 98:128-134. http://dx.doi.org/10.3168/jds.2014-7932.

Iwersen, M., U. Falkenberg, R. Voigtsberger, D. Forderung, and W. Heuwieser. 2009. Evaluation of an electronic cowside test to detect subclinical ketosis in dairy cows. J. Dairy Sci. 92:2618-2624. http://dx.doi.org/10.3168/jds.2008-1795.
Jawor, P. E., J. M. Huzzey, S. J. LeBlanc, and M. A. G. von Keyserlingk. 2012. Associations of subclinical hypocalcemia at calving with milk yield, and feeding, drinking, and standing behaviors around parturition in Holstein cows. J. Dairy Sci. 95:1240-1248. http://dx.doi.org/10.3168/jds.2011-4586.

Kaufman, E. I., S. J. LeBlanc, B. W. McBride, T. F. Duffield, and T. J. DeVries. 2016. Monitoring rumination in transition dairy cows for early detection of subclinical ketosis. J. Dairy Sci. 99:56045618. http://dx.doi.org/10.3168/jds.2015-10509.

LeBlanc, S. 2010. Monitoring metabolic health of dairy cattle in the transition period. J. Reprod. Dev. 56:S29-S35. http://dx.doi. org/10.1262/jrd.1056S29.

Ledgerwood, D. N., C. Winckler, and C. B. Tucker. 2010. Evaluation of data loggers, sampling intervals, and editing techniques for measuring the lying behavior of dairy cattle. J. Dairy Sci. 93:51295139. http://dx.doi.org/10.3168/jds.2009-2945.

Liboreiro, D. N., K. S. Machado, P. R. B. Silva, M. M. Maturana, T. K. Nishimura, A. P. Brandão, M. I. Endres, and R. C. Chebel. 2015. Characterization of peripartum rumination and activity of cows diagnosed with metabolic and uterine diseases. J. Dairy Sci. 98:6812-6827. http://dx.doi.org/10.3168/jds.2014-8947.

McArt, J. A. A., D. V. Nydam, and G. R. Oetzel. 2012. Epidemiology of subclinical ketosis in early lactation dairy cattle. J. Dairy Sci. 95:5056-5066. http://dx.doi.org/10.3168/jds.2012-5443.

Nordlund, K. V. 2009. The five key factors in transition cow management of freestall dairy herds. Pages 27-32 in Proc. 46th Dairy Prod. Conf., Gainesville, FL. University of Florida, Gainesville.

Proudfoot, K. L., J. M. Huzzey, and M. A. G. von Keyserlingk. 2009. The effect of dystocia on the dry matter intake and behavior of Holstein cows. J. Dairy Sci. 92:4937-4944. http://dx.doi. org/10.3168/jds.2009-2135.

Sepúlveda-Varas, P., D. M. Weary, and M. A. G. von Keyserlingk. 2014. Lying behavior and postpartum health status in grazing dairy cows. J. Dairy Sci. 97:6334-6343. http://dx.doi.org/10.3168/ jds.2014-8357.

Soriani, N., E. Trevisi, and L. Calamari. 2012. Relationships between rumination time, metabolic conditions, and health status in dairy cows during the transition period. J. Anim. Sci. 90:4544-4554. http://dx.doi.org/10.2527/jas.2012-5064.

Steensels, M., C. Bahr, D. Berckmans, I. Halachmi, A. Antler, and E. Maltz. 2012. Lying patterns of high producing healthy dairy cows after calving in commercial herds as affected by age, environmental conditions and production. Appl. Anim. Behav. Sci. 136:88-95. http://dx.doi.org/10.1016/j.applanim.2011.12.008

UBC AWP. 2013. UBC Animal Welfare Program: SOP - HOBO Data Loggers. University of British Columbia, Vancouver, Canada.

Voyvoda, H., and H. Erdogan. 2010. Use of a hand-held meter for detecting subclinical ketosis in dairy cows. Res. Vet. Sci. 89:344-351. http://dx.doi.org/10.1016/j.rvsc.2010.04.007.

Weary, D. M., J. M. Huzzey, and M. A. G. von Keyserlingk. 2009. Board-invited review: Using behavior to predict and identify ill health in animals. J. Anim. Sci. 87:770-777. http://dx.doi. org/10.2527/jas.2008-1297. 